\title{
DETERMINAN SOSIAL EKONOMI TENAGA KERJA INFORMAL TERHADAP KEPEMILIKAN JAMINAN KECELAKAAN KERJA DI INDONESIA : SUSENAS 2017
}

\section{INFORMAL LABOR SOCIO-ECONOMIC DETERMINANTS OF WORK ACCIDENT INSURANCE OWNERSHIP : SUSENAS 2017}

\author{
Sri Denti On Madya, Atik Nurwahyuni \\ Universitas Indonesia \\ (onmadya@yahoo.com/081513688617)
}

\begin{abstract}
ABSTRAK
Jumlah tenaga kerja informal lebih banyak dibandingkan dengan tenaga kerja formal di Indonesia. Cakupan kepemilikan jaminan kecelakaan kerja masih sangat rendah sedangkan angka kecelakaan kerja masih cenderung tinggi. Penelitian ini bertujuan untuk mengetahui determinan sosial ekonomi kepemilikan jaminan kecelakaan kerja pada tenaga kerja informal di Indonesia. Variabel yang diamati yaitu, umur, jenis kelamin, status pernikahan, keluhan kesehatan, pendidikan, wilayah dan sosial ekonomi/pendapatan tenaga kerja informal. Data yang digunakan adalah Data Susenas (Survei Sosial Ekonomi Nasional) tahun 2017 dan dianalisis dengan menggunakan regresi logistik/logit. Hasil penelitian menunjukkan bahwa ada hubungan antara umur, jenis kelamin, status pernikahan, pendidikan, wilayah dan sosial ekonomi/pendapatan tenaga kerja informal terhadap kepemilikan jaminan kecelakaan kerja di Indonesia.
\end{abstract}

Kata kunci : Sektor informal, Kecelakaan kerja, Logit

\section{ABSTRACT}

The number of informal workers is more than the formal workforce in Indonesia. The coverage of work accident insurance coverage is still very low while the work accident rate still tends to be high. This study aims to determine the socio-economic determinants of work accident insurance ownership in informal workers in Indonesia. The variables observed were age, sex, marital status, health, education, regional complaints and socio-economic / informal labor income. The data used are Susenas Data (National Socio-Economic Survey) in 2017 and analyzed using logistic / logit regression. The results showed that there was a relationship between age, sex, marital status, education, region and socioeconomic / informal labor income on job security insurance ownership in Indonesia.

Keywords : Informal sector, Work Accident, Logit

\section{PENDAHULUAN}

Sektor pekerjaan informal telah dikenal sebagai sebuah fenomena alami dibanyak negara berkembang. Keterlibatan di dalam ekonomi informal juga diasosiasikan dengan upah yang lebih rendah, pekerjaan yagn lebih sulit dan berbahaya, keamanan dan perlindungan yang lebih rendah serta banyak kerugian lainnya. Dengan kata lain, ekonomi informal mewakili sebuah kerja yang tidak layak tetapi di sisi lain ekonomi informal adalah sumber mata pencaharian dan perlindungan segera dari kemiskinan. sektor informal menawarkan solusi vepat terhadap kebutuhan banyak orang untuk mendapatkan penghasilan ${ }^{1}$

Dibanyak negara berkembang ekonomi informal mewakili setidaknya 2/3 dari total (formal/informal) non-pertanian. Di Asia Selatan dan Tenggara proporsi pekerja di sector informal melebihi pekerja informal di sector formal. Namun angka tertinggi pekerja informal di luar sektor informal berada diluar sector informal berada di India dan Vietnam. ${ }^{2}$

Pada 2013, satu pekerja di dunia meninggal setiap 15 detik karena kecelakaan kerja dan 160 pekerja mengalami penyakit akibat kerja. Tahun sebelumnya mencatat jumlah kecelakaan dan penyakit akibat kerja sebanyak 2 juta per tahun. Tercatat 6.000 kecelakaan fatal di dunia. Kasus kecelakaan setiap hari di Indonesia, sepertiganya berasal dari sektor konstruksi. Penyebab kecelakaan itu dipicu oleh kurangnya pendidikan di sektor konstruksi. Dari total angkatan kerja, ada 98100 ribu kasus setiap tahun sebanyak 121 juta orang. ${ }^{3}$

Jaminan sosial telah diamanatkan oleh UUD 1945 pasal 34 ayat 2 "Negara mengembangkan sistem jaminan social bagi seluruh rakyak dan memberdayakan masyarakat yang lemah dan tidak mampu", sementara jaminan sosial sektor informal 
diatur dalam pasal $28 \mathrm{H}$ ayat (3) disebutkan "setiap orang berhak atas jaminan sosial yang memungkinkan pengembangan dirinya secara utuh sebagai manusia yang bermartabat". Declaration of human right pasal 25 juga menyebutkan, "setiap warga negara berhak mendpat perlindungan jika mencapai hari tua, sakit, cacat, menganggur dan meninggal dunia.". Hal ini bertujuan memberikan perlindungan jaminan sosial bagi tenaga kerja luar hubungan kerja, pada saat tenaga kerja tesebut kehilangan sebagian atau seluruh penghasilannya sebagai akibat terjadinya risiko-risiko antara lain: kecelakaan kerja, hari tua, dan meninggal dunia . ${ }^{4}$

Kepesertaan Sektor informal masuk dalam kategori Bukan Penerima Upah (BPU). Menurut BPJS Ketenagakerjaan, pekerja BPU ini adalah mereka yang memiliki pekerjaan atau usaha ekonomi secara mandiri untuk memperoleh penghasilan dari kegiatan atau usahanya tersebut. Pekerja BPU ini meliputi pemberi kerja diluar hubungan kerja atau pekerja mandiri dan pekerja yang tidak termasuk pekerja diluar hubungan kerja yang bukan menerima upah. ${ }^{5}$ Jaminan kecelakaan kerja sektor informal memberikan salah satunya adanya biaya perawatan medis dan rehabilitasi bagi pekerja dimana fasilitas yang diperoleh jika harus dirawat di rumah sakit adalah fasilitas kelas satu dengan pertanggungan pengobatan minimal hingga 20 juta rupiah. Undang-undang mengamanatkan bahwa Jaminan ketenagakerjaan bersifat wajib bagi seluruh pekerja.

Direktur BPJS Ketenagakerjaan menyatakan dari sekitar 63 juta orang yang bekerja disektor informal, baru sekitar 1,4 juta orang yang aktif dalam program jaminan sosial ketenagakerjaan. ${ }^{6}$ Beban jaminan kesehatan tahun 2014 sampai 2016 yang meningkat dari 42,6 Triliun menjadi 67,2 Triliun menjadi isu adanya ketidakmerataan jaminan sosial di Indonesia yang dipengaruhi oleh berbagai hal. Dari latar belakang diatas perlu diketahui determinan social ekonomi tenaga kerja informal terhadap kepemilikan jaminan kecelakaan kerja.

Vol. XIV No. 2, Desember 2019

DOI: https://doi.org/10.32382/medkes.v14i2.717

\section{BAHAN DAN METODE}

Penelitian ini cross sectional dengan analisis bivariate menggunakan pendekatan model ekonometri. Jenis data yang digunakan dalam penelitian ini adalah data sekunder yang bersumber dari Data Survey Sosial Ekonomi Nasional (Susenas) tahun 2017. Unit analisis yang digunakan adalah tenaga kerja informal dengan usia minimal 15 tahun. Metode analisis yang digunakan dalam penelitian ini adalah metode estimasi Ordinary Least Square (OLS) dengan Logit model ${ }^{7}$ dan diolah menggunakan Stata.

\section{HASIL}

Hasil uji bivariat diketahui bahwa tenaga kerja informal yang berada di wilayah perkotaan lebih banyak memiliki jaminan kecelakaan kerja yaitu sebanyak 3.117 orang $(3,33 \%)$ dibandingkan di wilayah pedesaan sebanyak 2.619 orang $(1,28 \%)$. Persentasi kelompok umur tenaga kerja yang memiliki jaminan kecelakaan kerja berada pada usia $\geq$ 46 tahun yaitu sebesar 2,01\% atau sebanyak 2.516 orang. Sedangkan apabila dilihat dari variable jenis kelamin, tenaga kerja informal perempuan memiliki persentasi kepemilikan jaminan kecelakaan kerja yaitu sebesar 2,43\% atau sebanyak 2918 orang dibandingkan dengan tenaga kerja informal laki-laki yaitu sebesar $1,58 \%$ atau sebanyak 2.918 orang meskipun secara total jumlah tenaga kerja informal laki-laki lebih banyak dibandingkan dengan tenaga kerja informal perempuan. Hal yang menarik dari tabel diatas bahwa dari total tenaga kerja informal yang belum menikah dan sudah menikah memiliki persentase kepemilikan yang sama terhadap jaminan kecelakaan kerja yaitu sebesar 1,92\% padahal jumlah tenaga kerja informal yang sudah menikah itu lebih banyak dibandingkan dengan yang belum menikah. Selanjutnya tidak terdapat perbedaan yang terlalu jauh antar tenaga kerja informal yang tidak ada keluhan kesehatan dengan yang ada keluhan kesehatan terhadap kepemilikan jaminan kecelakaan kerja masing masing sebesar $1,93 \%$ dan $1,89 \%$. Sementara untuk tingkat 
pendidikan tinggi pada tenaga kerja informal memiliki lebih besar atas kepemilikan jaminan kecelakaan kerja yaitu sebesar 3,61\% dibandingkan dengan pendidikan rendah yaitu 1, 33 persen. Sebanyak 2.231 orang atau sebesar $5,17 \%$ tenaga kerja informal yang memiliki pendapatan yang sangat tinggi dan memiliki jaminan kecelakaan kerja dibandingkan dengan tenaga kerja informal dengan pendapatan sangat rendah yaitu sebanyak 305 orang atau $0,48 \%$ terhadap kepemilikan jaminan kecelakaan kerja.

Hasil uji asumsi logit diperoleh dihasilan pemodelan sebagai berikut :

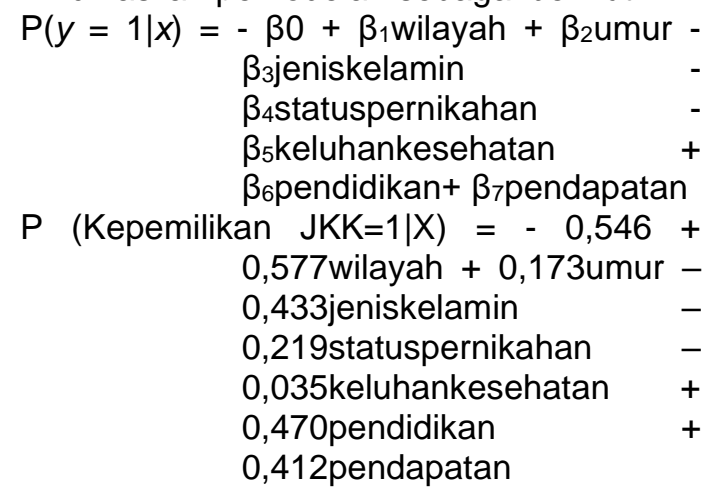

Dari pemodelan dihasilkan setiap penambahan 1 tenaga kerja informal pada wilayah perkotaan akan berpeluang menambah kepemilikan JKK sebesar 0,577. Setiap ke naikan umur 1 tahun tenaga kerja informal maka akan berpeluang meningkatkan kepemilikan JKK sebesar 0,173 kelamin tenaga kerja informal berpengaruh menurunkan kepemilikan JKK sebesar 0,433 Status pernikahan tenaga kerja informal berpengaruh menurunkan kepemilikan JKK sebesar 0,219 Status keluhan kesehatan tenaga kerja informal berpengaruh menurunkan kepemilikan JKK sebesar 0,035 Semakin tinggi tingkat pendidikan tenaga kerja informal akan berpeluang meningkatkan kepemilikan JKK sebesar 0,470 Setiap Peningkatan pendapatan tenaga kerja informal akan berpeluang meningkatkan kepemilikan JKK sebesar 0,412.

Berdasarkan hasil Ods ratio diatas dapat terlihat bahwa tenaga kerja informal yang berada diwilayah perkotaan akan berpeluang memilki JKK sebesar 1,7 kali dari yang tinggal di wilayah perdesaan. Sementara untuk kelompok umur yang berada pada $\geq 46$ tahun akan berpeluang memiliki JKK sebesar 1,08 kali lebih tinggi daripada kelompok umur 15-25 tahun dan 26-45 tahun. Dari jenis kelamin terlihat bahwa perempuan akan berpeluang sebesar 0,66 kali lebih besar untuk memiliki JKK dibandingkan dengan laki-laki. Sedangkan hasil ods rasio untuk status pernikahan menunjukkan bahwa tenaga kerja yang menikah berpeluang sebesar 0,92 kali lebih besar dari pada tenaga kerja yang tidak menikah untuk memiliki JKK. Tenaga kerja yang memiliki keluhan akan berpeluang untuk memiliki JKK sebesar 0,91 kali dari pada tenaga kerja informal yang tidak memiliki keluhan kesehatan. Semakin tinggi tingkat pendidikan tenaga kerja informal akan semakin berluang memiliki JKK yaitu sebesar 1,93 kali lebih tinggi dari pada tenaga kerja informal yang berpendidikan rendah. Demikian juga dengan tingkat pendapatan tenaga kerja informal yang sangat tinggi akan berpeluang memilkik JKK sebesar 1,6 kali lebih tinggi dari pada tenaga kerja yang berpenghasilan tinggi, mengengah. Dari hasil uji Hosmer-Lemeshow diketahui bahwa Prob $>$ chi2 sebesar 0,1181 yang berarti $\mathrm{H}_{0}$ diterima, sehingga model tersebut dapat menjelaskan variabel dependen.

\section{PEMBAHASAN}

Tenaga kerja informal sebagian besar berada di wilayah perdesaan dibandingkan dengan perkotaan. Secara signifikan variable ini berpengaruh terhadap kepemilikan jaminan kecelakaan kerja. Hal ini sesuai dengan hasil uji dimana angka tenaga kerja informal yang lebih sedikit di perkotaan tetapi memiliki jumlah kepemilikan JKK yang lebih besar dibandingkan dengan perdesaan. Hal ini dimungkinkan karena rendahnya akses informasi di daerah perdesaan serta rendahnya pengetahuan tenaga kerja informal terkait jaminan kecelakaan kerja. Hal ini dapat terlihat dari hasil uji variable pendidikan dimana dalam penelitian ini sebagian besar dari tenaga kerja informal memiliki pendidikan rendah yaitu sebesar $74,02 \%$ dari total responden Notoadmojo disebutkan bahwa akses pelayanan kesehatan adalah pelayanan kesehatan itu harus dapat dicapai oleh masyarakat, tidak terhalang oleh keadaan geografis, sosial, ekonomi, organisasi dan Bahasa ${ }^{8}$ lbok dalam oktora menjelaskan 
bahwa akses informasi mengenai asuransi kesehatan yagn diperoleh melalui media cetak dan iklan sangat membantu penyebaran informasi asuransi kesehatan. ${ }^{9}$

Secara jumlah tenaga kerja informal tidak terlalu jauh jumlahnya pada kelompok umur 26-45 tahun dengan usia 46 tahun keatas, tetapi secara kepemilikan jaminan kecelakaa kerja persentase kelompok usia 46 tahun keatas lebih tinggi dibandingkan dengan kelompok usia dibawahnya. Artinya semakin tinggi usia tenaga kerja informal maka kecenderungan untuk memiliki jaminan kecelakaan kerja akan semakin tinggi. Penelitiannya lain menyebutkan persentase kelompok pekerja informal cendering meningkat seiring bertambahnya usia. ${ }^{2}$

Secara total jumlah tenaga kerja informal dengan jenis kelamin laki-laki lebih besar dibandingkan dengan perempuan. Tetapi apabila dilihat dari status kepemilikan jaminan kecelakaan kerja dalam penelitian ini jumlah perempuan lebih banyak dibandingkan dengan laki-laki. Hal ini. Dilihat dari angka harapan hidup, laki-laki lebih tinggi dibandingkan dengan perempuan. Tetapi masalah kesehatan menurut jenis kelamin perempuan lebih rentan dibandingkan dengan laki-laki mengingat jaminan kecelakaan kerja memiliki santunan pelayanan kesehatan juga. Hal ini yang mungkin mempengaruhi kondisi tersebut. Hal ini sejalan dengan penelitian Baros yang menghasilkan penelitian terkait kepemilikan jaminan kesehatan cenderung lebih besar dibandingkan laki-laki. 10

Secara model ekonometeri status pernikahan memberikan pengaruh negative terhadap kepemilikan jaminan kecelakaan kerja. Artinya setiap penambahan status tenaga kerja informal yang menikah akan mengurangi angka kepemilikan jamiman kecelakaan kerja. Hal ini dimungkinkan karena semakin bertambahnya kebutuhan dari tenaga kerja informal sehingga memiliki kecenderungan untuk tidak memiliki jaminan kecelakaan kerja meskipun dalam penelitian ini secara perserntase tenaga kerja informal yang menikah dengan yang tidak menikah dalam hal kepemlikian jaminan kecelakaan kerja itu sama. Hal ini sejalan dengan penelitian lain dinyatakan bahwa penduduk yang belum pernah menikah akan lebih sedikit memiliki jaminan kesehatan dibandingkan dengan penduduk yang sudah pernah menikah. ${ }^{11}$

Secara keseluruhan dari tenaga kerja sector informal $71 \%$ menyatakan tidak ada keluhan kesehatan dalam 1 bulan terakhir dan secara statistic tidak bermakna terhadap kepemilikan jaminan kecelakaan kerja. hal ini tidak sejalan dengan penelitian lain yang menyebutkan bahwa keluharn kesehatan memiliki hubungan yang signifikan terhadap kepemilikan jaminan. Hal ini bisa saja terjadi karena keterbatasan penelitian dimana tidak ditemukannya secara detail jenis keluhan kesehatan terutama kecelakaan kerja dan penyakit akibat kerja dalam data yang dipakai sehingga secara statistic variable ini tidak bermakna.

Sebagian besar pendidikan tenaga kerja informal pada penelitian ini berada pada tingkat pendidikan rendah. Variable ini secara statistik bermakna terhadap kepemilikan jaminan kecelakaan kerja dan berdasarkan model ekonometri bernilai positif. Artinya kepemilikan jaminan kecelakaan kerja ini bergantung terhadap tingkat pendidikan atau tinggi rendahnya pengetahuan dari tenaga kerja informal. Secara keseluruhan jumlah kepemilikan jaminan kecelakaan kerja di Indonesia pada pekerja sector informal sangat rendah. Kondisi rendahnya tingkat pendidikan ini yang menjadi penyebab kondisi tersebut. Hal ini dapat juga terlihat dari proporsi tenaga kerja informal yang memiliki JKK sebagian besar berpendirikan tinggi. Penelitian serupa dilakukan bahwa responden yang memiliki tingkat pendidikan tinggi memiliki proporsi terbesar untuk memiliki jaminan social. Menurut Dartanto et. Al dalam rizal disebutkan bahwa alasan utama mengapa sektor informal tidak mendaftarkan diri dalam suatu jaminan salah satunya adalah karena ketidak tahuan tentang adanya jaminan. ${ }^{12}$

Social ekonomi / pendapatan pada tenaga kerja informal secara statistk bermakna terhadap kepemilikan jaminan kecelakaan kerja. Sebagain besar tenaga kerja informal dalam penelitian ini berada pada kategori pendapatan dengan tingkat menengah. Sehingga ini menjawab rendahnya kepemilikan JKK di Indonesia karena terkait dengan pembayaran iuran jaminan. Apabila dilihat dari kepemilikan jaminan kecelakaan pada variable social 
ekonom, tenaga kerja informal yang memiliki jaminan kecelakaan kerja terbesar berada pada tingkat pendapatan yang sangat tinggi. $\mathrm{Hal}$ ini sejalan dengan pernyataan diatas bahwa pendapatan sangat berpengaruh terhadap kepemilikan jaminan kecelakaan kerja. Ini membuktikan bahwa pentingnya pendapatan dalam hal kepemilikan jaminan. Dengan mayoritas pendidikan yang rendah ternyata apabila pendapatan yang tinggi ternyata berpengaruh terhadap kepemilikan jaminan (Vera, 1999)

\section{KESIMPULAN DAN SARAN}

\begin{abstract}
Penelitian ini mampu menjawab tujuan penelitian dengan menggunakan metode ekonometri dengan model logit. Dapat disimpulkan ada 3 faktor determinan yang paling berpengaruh terhadap kepemilikan jaminan kecelakaan kerja selain factor karakteristik tenaga kerja informal yaitu wilayah, pendidikan selanjutnya pendapatan. Pemerintah perlu memperhatikan pemerataan akses informasi terkait jaminan kecelakaan kerja, mempertimbangkan penghasilan/upah dari tenaga kerja sector informal serta pemerataan jaminan social dimasyarakat khususnya sector informal.
\end{abstract}

\section{DAFTAR PUSTAKA}

Baros, Wan Aisyiah, 2015. Faktor-Faktor Yang Mempengaruhi Kepemilikan Jaminan Kesehatan: Analisa data susenas 2013. Jurnal Kebijakan Kesehatan Indonesia.

Gujarati, D.N \& Porter D.C (2010) DasarDasar Ekonometrika (ed.5) Buku 1 (Euginia Mardanugraha, Sita Wadhani dan Carlos Mangunsong), Jakarta, Salemba Empat.

Vol. XIV No. 2, Desember 2019

DOI: https://doi.org/10.32382/medkes.v14i2.717
Littik, serli, 2007. Faktor-faktor yang berhubungan dengan kepemilikan asuransi di Provinsi Nusa Tenggara Timur. Jurnal MKM, Vol. 03, No. 02. Desember 2007.

Indonesia, 2004. Undang-undang Sistem Jaminan Sosial Nasional no. 40 Tahun 2004.

Muthahhari, 2017. Nasib Malang para pekerja Sektor Informal, diakses dari dari https://tirto.id/nasib-malang-parapekerja-sektor-informal-cyT9.

Noeraini, Astrid. A.,2015. Ekonomi Informal di Indonesia, Suatu Tinjauan Pustaka. Jurnal Jp Feb Unsoed Journal proceeding, 2015.

Notoadmodjo, S, 2003. IImu Kesehtan Masyarakaat. Jakarta: Rineka Cipta.

Oktora, 2016. Determinan Willingness to pay iurang jaminan kesehatan pada pekerja sector informal (pengemudi ojek pangkalan) kota depok tahun 2016: tesis, depok 2016.

Taufiq, N, 2017. Pengaruh Dinamika Sektor Pekerjaaan terhadap Dinamika kemiskinan di Indonesia: The effect of employment dinamics in Indonesia: Akses via website e-journal kemsos.go.id, 2017.

Rizal, 2017. Meyoal Kepesertaan Pekerja Sektor Informal pada Jaminan Kesehatan Nasional (JKN). Akses internet.

Rochmi, Nur Muhammad, 2016. Kecelakaan Kerja Sektor Konstruksi Paling Tinggi. Diakses Januari 2019.

Utama, Gwendolyn Ingrid, 2015. Kesempatan Jaminan Sosial bagi pekerja Sektor Usaha-Informal.

Vera, Hernandez, A.M, 1999. Duplicate Covarege and Demand for Health Care: The Case of Catalonia. Health Economics 8. 